\section{Painting Aluminum Strips on Black Plastic Mulch Reduces Mosaic Symptoms on Summer Squash}

\author{
W.J. Lamont', K.A. Sorensen', and C.W. Averre ${ }^{3}$ \\ North Carolina State University, Raleigh, NC 27695
}

Additional index words. Cucurbita pepo, reflective mulches, watermelon mosaic virus II

Aphid-borne virus diseases limit production of yellow squash (Cucurbita pepo L.) in North Carolina in most fall seasons. Watermelon mosaic virus II (WMVII) is the most common causal agent. It is a nonpersistent, aphid-borne virus that is acquired and transmitted in a matter of seconds from weed and cucurbit species hosts. Aphid vectors of WMVII include the spirea aphid (Aphis citricola Van der Goot), the erigeron root aphid (Aphis middletonii Thomas), the grapevine aphid (Aphis illinoisensis Shimer), and the green peach aphid (Myzus persicae Sulzer) (Adlerz, 1987). The random probing of hosts and nonhosts by winged aphids makes acceptable control of nonpersistent viruses by approved insecticide spray programs extremely difficult, if not impossible (Broadbent, 1957).

The ability of reflective aluminum foil or paper-backed aluminum foil to reduce the incidence of aphid-borne virus has been well documented (Smith et al., 1964). Aluminum foil mulch repelled aphids and reduced virus disease in yellow straightneck squash (George and Kring, 1971). The newer reflective, metallic mulches and reflective white mulches have been shown to elicit various levels of detergency of aphids and thus reduce the incidence of mosaic on yellow summer squash (Chalfant et al., 1977).

This study was undertaken to determine the repellency and cost effectiveness of various combinations of painted aluminum stripping on standard black embossed mulch film and other reflective mulches, as measured by the reduced incidence of mosaic symptoms on squash fruit.

Afield experiment was conducted in 1985 at Central Crops Research Station, Clayton,

Received for publication 12 Oct. 1989. Paper no. 11916 of the Journal Series of the North Carolina gratefully acknowledge the support of W.R. Baker, Sta. Supt., Central Crops Res. Sta., and the technical assistance of K.A. Kidd and D.E. Adams. Use of trade names in this publication does not imply endorsement by the North Carolina Agricultural Research Service of the products named, nor criticism of similar ones not mentioned. The cost of publishing this paper was defrayed in part by the payment of page charges. Under postal regulations, this paper therefore must be hereby marked advertisement solely to indicate this fact.

'Assistant Professor. Present address: Dept. of Horticulture, Kansas State Univ., Manhattan, KS 66506.

Professor, Dept. of Entomology.

${ }^{3}$ Professor, Dept. of Plant Pathology. plied at that time, with the drip irrigation Agr. Res. Serv., Raleigh, NC 27965-7643. We
N. C., on a Marlboro loamy soil (Typic Paleudults; fine-loamy, siliceous, thermic). Plots were arranged in a randomized complete-block design with four replications and consisted of three beds $0.76 \mathrm{~m}$ wide and $6.1 \mathrm{~m}$ long on $1.5-\mathrm{m}$ centers. We used gray metallic mulch (GM) (North American Film Corp., Bridgeport, $\mathrm{Pa}$.), white mulch (WM), embossed black mulch (EBM), and embossed black mulch films with either two $25-\mathrm{cm}$ wide painted aluminum strips on the edge of the mulched bed (EBM-edge) or a $25-\mathrm{cm}-$ wide painted aluminum strip down the center of the mulched bed (EBM-center), and bare ground. The all-purpose aluminum paint (Black Jack) was diluted 1:2 with mineral spirits paint thinner.

Fertilizer $\left(240 \mathrm{~N}-\mathrm{OP}-247 \mathrm{~K}, \mathrm{~kg} \cdot \mathrm{ha}^{-1}\right)$ was broadcast and disked before bed preparation and before laying the mulches. The plots were fumigated with methyl bromide at a broadcast rate of $269 \mathrm{~kg} \cdot \mathrm{ha}^{-1}$ on $6 \mathrm{Aug}$. Mulch films and drip irrigation tubing were also aptubing placed on each bed $8 \mathrm{~cm}$ from the center line and $8 \mathrm{~cm}$ deep. Irrigation at 4 $\mathrm{mm} \cdot \mathrm{hr} \mathrm{r}^{-1}$ was supplied when soil water potential at $15-\mathrm{cm}$ depth reached $-0.25 \mathrm{kPa}$, as determined by use of tensiometers in bareground plots. Black polyethylene mulch was applied to the bare-ground plots to permit adequate fumigation but was removed the day of seeding.

On 8 Aug., 15-cm-diameter holes were punched in the center of the plastic at $30-\mathrm{cm}$ spacing. On 12 Aug., aluminum strips were applied with paint rollers.

On 13 Aug., 'Early Prolific Straightneck' yellow summer squash was seeded in prepunched holes. Plots were harvested a total of 17 times beginning 18 Sept. Plants in the center row were examined for mosaic virus

Table 1. The influence of reflective mulch on incidence of mosaic on 'Early Prolific Straightneck' summer squash fruit.

\begin{tabular}{lccccc}
\hline & \multicolumn{2}{c}{ Yield (fruit/ha; thousands) } & & \multicolumn{2}{c}{ Fruit affected (\%)y } \\
\cline { 2 - 3 } Mulch & Total & Marketable & & Mosaic & Cull \\
\hline Gray metallic & 146.3 & 103.9 & 25 & 4 \\
White & 148.5 & 95.0 & 32 & 4 \\
Black/aluminum & 119.0 & 89.3 & 20 & 5 \\
$\quad$ strip on edge & & & & 36 & 7 \\
Black/aluminum & 114.7 & 65.4 & & 50 & 4 \\
$\quad$ strip in center & 133.2 & 61.3 & 66 & 5 \\
Black & 90.6 & 26.3 & 9 & 9 \\
Control (no mulch) & 41.3 & 9.5 & & & \\
LSD 0.05 & & & &
\end{tabular}

${ }^{2}$ Harvest period 18 Sept.-25 Oct.

yll percentages were subjected to angular transformation before calculation of the means. of fruit with mosaic symptoms.

To repel aphids and delay the onset of mosaic symptoms in fall-grown yellow squash fruit, the greatest amount of highly reflective surface area for the longest period of time must be provided. The rapidly growing squash plant quickly covered the reflective surface of the EBM-center, reducing its performance to that of the EBM.

The cost per hectare of WM would be about $\$ 1300$, of GM about $\$ 1000$, and the EBMedge about $\$ 750$. The black mulch with aluminum strips is an extremely cost-effective way to maintain marketable yield by reducing losses due to mosaic. Nevertheless, by the end of the season, even the best treatments had fruit with extensive virus symptoms. Hence, reflective films and aluminum paint only delay virus symptoms, but they do extend the harvest season and likely would increase returns.

\section{Literature Cited}

Adlerz, W.C. 1987. Cucurbit polyvirus transmission by slate aphid (Homoptera-Aphididae) trapped alive. J. Econ. Ent. 80:87-92.

Broadbent, L. 1957. Insecticidal control of the spread of plant viruses. Annu. Rev. Ent. 2:239354

Chalfant, R. B., C.A. Jaworski, A.W. Johnson, and D.R. Summer. 1977. Reflective film mulches, millet borers and pesticides: Effects on watermelon mosaic virus, insects, nematodes, soil borne fungi and yield of yellow summer squash. J. Amer. Soc. Hort. Sci. 102:1115

George, W. L., Jr., and J.B. Kring. 1971. Virus protection of late season summer squash with aluminum mulch. Conn. Agr. Expt. Sta. Bul. 239.

Smith, F. F. G.V. Johnson, R.P. Kahn, and A Bing. 1964. Repellency of reflective aluminum to transient aphid virus-vectors. Phytopathology $54: 748$ symptoms 25 Sept. and 18 Oct. The center row of each plot was harvested and the fruit evaluated for mosaic symptoms, including degrees of discoloration and malformation that would make it unsalable. WMV-II was identified serologically from symptomatic plants by the Plant Disease and Insect Clinic, North Carolina State Univ.

Virus disease was extremely prevalent throughout the season (Table 1). GM and EBM-edge reduced mosaic symptoms the most. WM and EBM-center were slightly less effective. The EBM and control (no mulch) treatments resulted in the highest percentage

HORTSCIENCE, Vol. 25(10), OCTOBER 1990 